\title{
Economics of Happiness: A Social Study on Determinants of Well-Being among Employees in a State University
}

\author{
Leomarich F. Casinillo ${ }^{1}$, Emily L. Casinillo ${ }^{2}$, and Ma. Rachel Kim L. Aure ${ }^{3}$ \\ ${ }_{1,2,3}$ Visayas State University, Baybay City, Leyte, Philippines
}

\section{Article history:}

Submitted: 11 February 2021

Revised: 14 March 2021

Accepted: 25 March 2021

\section{Keywords:}

Happiness

Socio-economic determinants

Well-being

Econometric modeling

State University

Philippines
ABSTRACT. This study aimed to elucidate the level of happiness and its influencing determinants among employees (teaching and non-teaching) of Visayas State University, Baybay City, Leyte, Philippines. With the aid of purposive sampling, the study engaged 162 employees as participants in the survey to gather richer information. The study utilized primary data, which were collected through a developed and structured questionnaires. The data were analyzed through descriptive analysis and econometric modeling. Results revealed that non-teaching employees are more likely happy working in a university. It was found out that the predictors of happiness in working in a university are: age, years in service, permanent status, opportunities for promotion, and fair administration. Employees found their respective jobs as challenging, enjoyable and rewarding. However, results showed that income is not a determinant of employees' happiness. Furthermore, employees who are socially oriented and physically healthy are more likely happy workers.

\subsection{Introduction}

In the study of De Stasio et al. (2019), it is revealed that subjective happiness has shown a positive effect on the level of work engagement. Happiness in teaching is valuable in the learning environment and useful in imparting knowledge to students (Casinillo et al., 2020). According to Stutzer and Frey (2012), happiness research in economics gets reported subjective well-being as a substitute measure for individual welfare. Subjective well-being is applied in psychology for an individual's evaluation of the extent to which he or she undergoes positive and negative results, happiness, or satisfaction with life (Stutzer \& Frey, 2010; Kahneman \& Krueger, 2006). The economic study of individual happiness is based on acknowledging that everyone has their concepts about happiness and the good life. That unveiled behavior is an inadequate indicator of individual wellbeing. Individuals' well-being can nevertheless be seized and examined: individuals can be asked how satisfied they are with their lives. They are expected to be good judges of the overall quality of their lives, which can be used for research in advancing policy implications (Frey \& Stutzer, 2012).

Happiness is the ultimate goal of human life, where everybody lives life for satisfaction and happiness (Guazzelli \& Zilli, 2016). As defined in the Meriam-Webster dictionary, happiness is a wellbeing and contentment state, a pleasurable or satisfying experience. Happiness is a long-term emotional state that varies in every person; hence happiness is subjective. The concept of happiness varies from one person to another. A certain individual may be happy with something, while others may not. Happiness depends on how individuals view things and live their life. According to Graham (2004), economic status in emerging market countries affects a person's happiness. They further confirm that higher educational attainment, more income, and regular job results positively affect a person's happiness. Individual experiences and achievements and quality of working life are meaningful determinants of happiness (Štreimikienè \& Grundey, 2009).

Nevertheless, psychologists, sociologists, and a small but increasing number of economists show that happiness level is affected by income level, but only slightly ( $\mathrm{Ng}, 2002)$. In converse, happiness appears to motivate greater effort, boosting output without influencing its quality and increasing productivity. Both a momentary increase in happiness and long-term baseline happiness changes are linked with greater productivity (Proto, 2016). Various current studies show that income does not influence life satisfaction or happiness (Casinillo, 2020; Casinillo et al., 2020; Guazzelli \& Zilli, 2016). That is, the positive effects of extra income on our quality of life are surprisingly little. Most researchers concluded that well-being satisfaction is heavily influenced by personality factors and personal and social relationships (Štreimikiene \& Grundey, 2009). Concentrating solely on income can miss other essential elements of welfare. Each individual has distinct preferences over material 
and non-material things. For instance, one may prefer a lower-paying but more personally rewarding job (Graham, 2005).

This research study highlights the investigation of socio-economic factors' effects on the happiness experienced by Visayas State University (VSU) teaching and non-teaching employees. The happiness of the employees in the workplace is known to increase productivity and efficiency. To date, little work is done about establishing a relationship between happiness and socio-economic factors of the VSU employees using the econometrics approach. The economics of happiness is known to be a novel approach that provides alternative measures of well-being, which focuses on the aspects of the process that also matter to one's welfare (Graham, 2005). Understanding the economics of happiness of employees will elucidate a deeper sense of satisfaction in the workplace. Hence, this study aimed to investigate the socio-economic factors that affect VSU employees' happiness and examine whether this lifestyle contributes to a happy life. Specifically, it aimed to answer the following objectives: (1) to characterize the demographic profile of VSU employees; (2) to estimate the level of happiness and its possible influencing factors among employees; (3) to document significant determinants that would affect happiness among employees; (4) to provide some policy inputs that will both benefits employees and administration. This study can provide an informed decision for school administrators, particularly in educational services and school monitoring. The results can serve as baseline data for information to adopt this kind of research in their respective workplace. Further, this will contribute to the body of knowledge concerning employees' happiness and satisfaction. The study will also provide additional insights to policymaking bodies to justify work practices to boost happiness and assess employees' welfare.

\subsection{Framework of the Study}

Happiness at work is when a person reacts to and enjoys what he or she is doing. It also means when personnel is happy working and not thinking like it is work, efficient and realizes targeted goals, both at the personnel and organizational levels (Maenapothi, 2007). Economics of happiness does not replace income-based measure of a person's welfare but instead complement them with broader determinants to measure well-being (Graham 2004). The framework is grounded on different factors of happiness in the current papers by Casinillo et al. (2020), Guazzelli and Zilli (2016), and Mertoğlu (2018), which is designed to investigate the implications of socio-economic factors and predictors on the feeling of happiness among employees. Figure 1 shows the conceptual framework of this study.

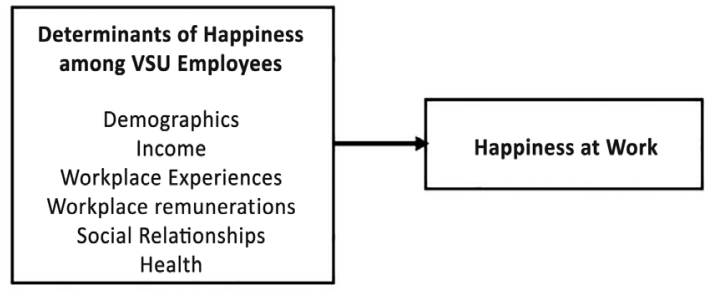

Figure 1. Conceptual Model

\subsection{Methods}

The design used in this study was quantitative, that is, the descriptive-correlational design which will seek factors affecting VSU employees' happiness. The research design was based on the current paper by Casinillo et al. (2020), which deals with econometric modeling. For data gathering, primary data on the demographic profile, level of happiness, and determinants were considered using developed questionnaires based on literature (Guazzelli \& Zilli, 2016; Mertoğlu, 2018). In data analysis, descriptive statistics were computed, and econometric modeling was undertaken in determining influential factors of the well-being of VSU employees.

Before the conduct of this survey, the president of VSU was requested through a formal letter. Then, all teaching and non-teaching staff who are currently employed in Visayas State University of five campuses (Baybay City, Isabel, Alangalang, Tolosa, and Villaba) during the study's conduct comprised the population of interest. The lists of faculty and staff with its ranking position were 
sought in the University's human resource office. Each campus was considered a stratum. In choosing the desired respondent for this research, purposive sampling was used for each stratum. This survey produced participants that were logically assumed to represent the population, which best enabled them to answer the research questions. Upon retrieving the questionnaires, researchers only collected about $10 \%$ of the respondents' overall total number due to uncontrolled circumstances (i.e., COVID 19 Pandemic) during the survey. On the other hand, the study also aimed to gather more data and richer information about its well-being. Hence, the study has 162 employees (teaching and nonteaching staff) in the University.

A structured questionnaire was constructed to determine the level of happiness, demographic profile, and influencing determinants for data gathering. The questionnaire is divided into three sections. The first section was on the respondents' socio-demographic profile. The second section was about the determinants of happiness. The third section was about the level of happiness. This set of instruments was adopted from the studies of Guazzelli and Zilli (2016) and Chaiprasit and Santidhirakul (2011), which is designed to investigate the implications of socio-economic factors and determinants on the feeling of happiness among employees.

Furthermore, the questionnaire for happiness level was based on the study of Lyubomirsky and Lepper (1999). A 3-item scale was designed to measure the subjective happiness of the respondents. Each of the items is completed by choosing one of 10 options that finish a given sentence fragment, that is, 1-very unhappy and 10-very happy. Before the conduct of the study, the research questionnaire was undergone pretesting. With the aid of Statistical Packages for the Social Sciences (SPSS) v.20, it is found out that the instrument is reliable with Cronbach's $\alpha$ equal to 0.86 . Tables 1 shows the different range of values of the employees' mean of happiness scores and its corresponding description.

Table 1. Mean happiness score and its corresponding description

\begin{tabular}{ll}
\hline Range of Mean Happiness Score & Description \\
\hline $1.00-2.80$ & Very unhappy \\
$2.81-4.60$ & Unhappy \\
$4.61-6.40$ & Neutral \\
$6.41-8.20$ & Happy \\
$8.21-10.00$ & Very Happy \\
\hline
\end{tabular}

In describing the data gathered for this study, descriptive measures were computed. In the econometric models, the mean perception score of happiness among VSU employees was considered the dependent variable. The first econometric model was Ordinary Least Square (OLS). Since the dependent variable is ordinal, then the second econometric model was the ordered logit model. For the OLS model, a scale from 1 to 10 was considered. For the ordered logit model, the dependent variable was categorized as follows: (1-3)-Unhappy, (4-6)-Neutral, and (7-10)-Happy. The first econometric model is given by:

$$
\begin{aligned}
\text { Happiness }_{i} & =\beta_{0}+\beta_{1} \text { Teaching }_{i}+\beta_{2} \text { Age }_{i}+\beta_{3} \text { Male }_{i}+\beta_{4} \text { Married }_{i}+\beta_{5} \text { Urban }_{i} \\
& +\beta_{6} \text { Educ }_{i}+\beta_{7} \text { Service }_{i}+\beta_{8} \text { Permanent }_{i}+\beta_{9} \text { Income }_{i} \\
& +\beta_{10} \text { Otherincome }_{i}+\beta_{11} \text { FairAdmin }_{i}+\varepsilon_{i}
\end{aligned}
$$

where $i$ denotes the $i^{\text {th }}$ employee in the sample survey, $\beta_{d} \beta_{1^{1}} \beta_{2} \ldots, \beta_{11}$ are parameters to be estimated, and $\varepsilon_{i}$ is the random errors in the model. Happiness is the level of happiness (scale of 1-10), Teaching is a dummy variable that captures a teaching employee, Age $_{i}$ is the age of employee measured in years, Male $_{i}$ is a dummy variable that captures the male employee ( $1=$ male and $0=$ female$)$, Married is a dummy variable that captures the married employee (1-Married, 0 -Not married), $U_{r b a n}$ is a dummy variable that captures a student who lives in an urban place ( $1=$ urban and $0=$ rural), Educ refers to the employee's level of education, Service ${ }_{i}$ refers to the number of years in service, Income refers to the monthly net income in peso, Otherincome is a dummy variable that captures employee with other income ( $1=$ With other income and $0=$ Without other income), FairAdmin ${ }_{i}$ and refers to employees' perception to the fairness of the administration (scale of 1-10). The second econometric model is given by: 


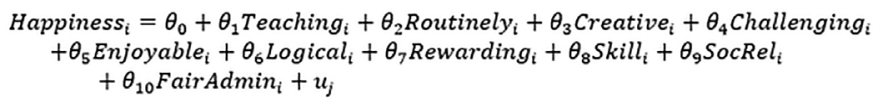

where $\theta_{\alpha^{\prime}} \theta_{1^{\prime}} \theta_{2^{\prime}} \ldots, \theta_{10}$ are parameters to be estimated, $u_{i}$ is the random error in the model, Routinely refers to employees' perception of how routinely is their work (scale of 1-10), Creative ${ }_{i}$ refers to employees' perception of how creative is their work (scale of 1-10), Challenging r refers to employees' perception of how challenging is their work (scale of 1-10), Enjoyable refers to employees' perception of how enjoyable is their work (scale of 1-10), Logical ${ }_{i}$ refers to employees' perception of how logical is their work (scale of 1-10), Rewarding refers to employees' perception of how rewarding is their work (scale of 1-10), Skill, refers to employees' perception of how their skill matches their job (scale of 1-10), SocRel, and refers to employees' perception of their social relationships. Lastly, the third econometric model is given by:

$$
\begin{aligned}
\text { Happiness }_{i} & =\partial_{0}+\partial_{1} \text { SoSecurity }_{i}+\partial_{2} \text { Educ }_{i}+\partial_{3} \text { OPromotions }_{i}+\partial_{4} \text { Bonus }_{i} \\
& +\partial_{5} \text { Incentives }_{i}+\partial_{6} \text { Award }_{i}+\partial_{7} \text { OPay }_{i}+\partial_{8} \text { SocRel }_{i}+\partial_{9} \text { Health }_{i}+\delta_{i}
\end{aligned}
$$

where $\partial_{0}, \partial_{1}, \partial_{2}, \ldots, \partial_{9}$ are parameters to be estimated, $\delta_{i}$ is the random error in the model, SoSecurity $i$ refers to employees' perception of their social security (scale of 1-10), OPromotions, refers to employees' perception of the opportunities to promotion in the University (scale of 1-10), Bonus refers to employees' perception regarding bonuses (scale of 1-10), Bonus refers to employees' perception regarding bonuses (scale of 1-10), Incentives refers to employees' perception regarding incentives (scale of 1-10), Awards refers to employees' perception regarding awards (scale of 1-10), OPay refers to employees' perception regarding overtime pay (scale of 1-10), SocRel refers to employees' perception of their social relationship (scale of 1-10), Health ${ }_{i}$ and refers to employees' perception of their health (scale of 1-10). Some diagnostic tests were obtained to ensure the econometric models' validity, and statistical calculations were employed with STATA v.14.

\subsection{Results and Discussion}

\section{Descriptive Statistics}

Table 2 reveals that the employees in VSU are considered happy $(\mu=7.79, \sigma=1.73$ ) (See Table 1 for details). The result is consistent with the study of Delfino (2019) that deals with the satisfaction of teaching and non-teaching personnel in a university. The age of the employees in VSU ranges from 22 to 65 years old $(\mu=39.17, \sigma=12.91)$, and there are $36 \%$ males and $64 \%$ females. About $59 \%$ of these employees are married, and about $25 \%$ live in urban places. On average, employees in VSU were graduates of Bachelor's degree $(\mu=2.64, \sigma=1.57)$. Employees with elementary and high school educational attainment levels are mostly Job Order $(\mathrm{JO})$ workers in the University. About $63 \%$ of the university employees are teaching staff, and $37 \%$ are composed of administrative staff and JO workers. The employees' average years of service are closed to 12.76 , and about $58 \%$ of these employees have a permanent status.

The monthly net income ranges from 5000 to $219000(\mu=24447.53, \sigma=25989.84)$. About $79 \%$ of them have other income aside from their salary in the University. The maximum income is the net salary of the University president whose academic rank is University professor. The University is considered fair and has fewer anomalies in administration $(\mu=7.59, \sigma=2.20)$. Perhaps, employees rated as satisfied with the following job experiences: routinely $(\mu=7.04, \sigma=2.60)$, creative $(\mu=7.91$, $\sigma=1.45)$, challenging $(\mu=8.56, \sigma=1.46)$, enjoyable $(\mu=8.10, \sigma=1.75)$, logical $(\mu=8.20, \sigma=1.66)$ and rewarding $(\mu=7.62, \sigma=1.97)$. These results are parallel to Casinillo et al. (2020), which investigates the experiences in teaching. Employees also said that their respective jobs and assignment matches their skills and degree finished $(\mu=8.33, \sigma=1.59)$. Perhaps, on average, these employees declared that they are socially secured in their workplace $(\mu=7.17, \sigma=3.03)$. On the average, employees are satisfied with the following remunerations in working in the University: opportunities to promotions $(\mu=7.27, \sigma=2.60)$, bonus $(\mu=7.95, \sigma=3.32)$, incentives $(\mu=7.38, \sigma=3.39)$, and awards $(\mu=6.94, \sigma=2.92)$. However, employees have a negative perception of the overtime pay $(\mu=4.27, \sigma=3.30)$. This implies that employees are working beyond office hours due to many work assignments without enough compensation. Furthermore, results reveal that employees are considered as socially-oriented $(\mu=8.59, \sigma=1.41)$ and physically healthy $(\mu=7.17, \sigma=3.03)$. 
Table 2. Descriptive statistics for variables of interest in the study $(n=162)$

\begin{tabular}{|c|c|c|c|c|}
\hline & $\min$ & $\max$ & SD & Mean \\
\hline Actual Happiness $^{\mathrm{a}}$ & 1 & 10 & 1.73 & 7.79 \\
\hline Age (in years) & 22 & 65 & 12.91 & 39.17 \\
\hline Male (dummy) & 0 & 1 & 0.48 & 0.36 \\
\hline Married (dummy) & 0 & 1 & 0.49 & 0.59 \\
\hline Urban(dummy) & 0 & 1 & 0.44 & 0.25 \\
\hline Educational Attainment ${ }^{b}$ & 1 & 6 & 1.57 & 2.64 \\
\hline Teaching (dummy) & 0 & 1 & 0.48 & 0.63 \\
\hline Years in Service & 0.25 & 45 & 12.17 & 12.77 \\
\hline Regular Permanent (dummy) & 0 & 1 & 0.49 & 0.58 \\
\hline Monthly Net Income in VSU' & 5000 & 219000 & 25989.84 & 24447.53 \\
\hline Other Income (dummy) & 0 & 1 & 0.87 & 0.79 \\
\hline Fair Administration $^{\mathrm{a}}$ & 1 & 10 & 2.20 & 7.59 \\
\hline Teaching experience: Routinely ${ }^{\mathrm{a}}$ & 1 & 10 & 2.60 & 7.04 \\
\hline Teaching experience: Creative $\mathrm{a}^{\mathrm{a}}$ & 1 & 10 & 1.45 & 7.91 \\
\hline Teaching experience: Challenging ${ }^{a}$ & 1 & 10 & 1.46 & 8.55 \\
\hline Teaching experience: Enjoyable & 1 & 10 & 1.75 & 8.10 \\
\hline Teaching experience: Logical ${ }^{\mathrm{a}}$ & 1 & 10 & 1.66 & 8.20 \\
\hline Teaching experience: Rewarding ${ }^{\mathrm{a}}$ & 1 & 10 & 1.97 & 7.62 \\
\hline Matches ones Skill ${ }^{\mathrm{a}}$ & 1 & 10 & 1.59 & 8.33 \\
\hline Social Security & 1 & 10 & 3.03 & 7.17 \\
\hline Opportunities for Promotion ${ }^{\mathrm{a}}$ & 1 & 10 & 2.60 & 7.27 \\
\hline Bonus $^{a}$ & 1 & 10 & 3.31 & 7.95 \\
\hline Incentives $^{\mathrm{a}}$ & 1 & 10 & 3.39 & 7.38 \\
\hline Awards ${ }^{\mathrm{a}}$ & 1 & 10 & 2.92 & 6.94 \\
\hline Overtime Pay ${ }^{\mathrm{a}}$ & 1 & 10 & 3.30 & 4.27 \\
\hline Social Relationship ${ }^{a}$ & 1 & 10 & 1.41 & 8.59 \\
\hline Health $^{\mathrm{a}}$ & 1 & 10 & 3.03 & 7.17 \\
\hline
\end{tabular}

\section{Econometric Models}

In the first model, it was found out that the variances are not heteroscedastic $\left(\chi^{2}=3.14\right.$, $p$-value $<0.0765$ ) at a $5 \%$ level of significance by Breusch-Pagan test (Table 3). By Ramsey RESET test $(F=2.39, p$-value $=0.071)$, the model has no omitted variables bias at a $5 \%$ level of significance. It was also found out that the model had no problem of multicollinearity between pair of predictors (mean $\mathrm{VIF}=2.52<10)$. Moreover, by the Shapiro-Wilk test, it is revealed that the residuals are normal $(Z=4.84$, $p$-value $<0.001)$, however, by Kernel density graph shows that the residuals are close to normality. Both OLS and ordered logit models were significant at a $1 \%$ level, which implies that the econometric determinants explain the variation of the degree of happiness among employees of VSU. In model 1 , the following determinants are not significant for both OLS and ordered logit: nature of work, gender, marital status, hometown, and income. This implies that the variables mentioned above do not govern the degree of happiness of the employees.

Table 1 further shows that the employees' age is both significant in OLS and ordered logit model. This implies that an older employee is more likely to be happy working in VSU. Older employees are more experienced in their assigned job, hence more productive, which is advantageous compared to the younger employees. This is somehow consistent with the studies of Kooij et al. (2011) and Truxillo and Fraccaroli (2013). However, years in service negatively affect happiness in the ordered logit model (Table 3). This implies that the lower number of years in service is more likely happy in their job. Employees with a higher number of services feel boredom due to the routine experience in the workplace. This result is parallel to Park et al. (2016) 's findings that young employees are more satisfied with their work. Hence, employees should be given new and feasible tasks related 
to their field to keep their passion in work and eliminate boredom. Both OLS and ordered logit in Table 3 reveal that a permanent status in job positively influences the employees' level of happiness. Permanent status gives employees a sense of security in their work; hence they are confident and less worried that they may not be renewed in their position (Galup et al., 2008; Perry, 2018). Furthermore, there is strong evidence to indicate that fair administration influences the degree of happiness among employees at a $1 \%$ level, as shown in Table 3. The result is consistent with the study of Fryxell and Gordon (1989) and Agwu (2013). This means that the transparency in the administration results in the good well-being of its employees.

Table 3.Econometric models for the degree of happiness in working VSU and its influencing determinants (Model 1)

\begin{tabular}{|c|c|c|c|c|}
\hline \multirow{2}{*}{$\begin{array}{c}\text { Determinants of } \\
\text { Happiness }\end{array}$} & \multicolumn{2}{|c|}{ OLS Model 1} & \multicolumn{2}{|c|}{ Ordered Logit Model 1} \\
\hline & Coefficient (b) & Std. Error (c) & Coefficient (b) & Std. Error (c) \\
\hline Constant & $\begin{array}{c}3.8808^{* * *} \\
(0.001)\end{array}$ & $\begin{array}{l}1.1910 \\
(3.260) \\
\end{array}$ & & \\
\hline $\begin{array}{l}\text { Dummy: Teaching } \\
\text { Faculty }\end{array}$ & $\begin{array}{c}-0.1162^{n s} \\
(0.831)\end{array}$ & $\begin{array}{c}0.5431 \\
(-0.210)\end{array}$ & $\begin{array}{c}-0.3385^{n s} \\
(0.633)\end{array}$ & $\begin{array}{l}0.7096 \\
(-0.48)\end{array}$ \\
\hline Age (in years) & $\begin{array}{c}0.0332^{* *} \\
(0.045)\end{array}$ & $\begin{array}{l}0.0165 \\
(2.020)\end{array}$ & $\begin{array}{c}0.6079^{* * *} \\
(0.003)\end{array}$ & $\begin{array}{l}0.0208 \\
(2.92)\end{array}$ \\
\hline Dummy: Male & $\begin{array}{c}0.0305^{n s} \\
(0.905)\end{array}$ & $\begin{array}{l}0.2536 \\
(0.120)\end{array}$ & $\begin{array}{c}0.1659^{n s} \\
(0.593)\end{array}$ & $\begin{array}{l}0.3101 \\
(0.53)\end{array}$ \\
\hline Dummy: Married & $\begin{array}{c}0.1212^{n s} \\
(0.551)\end{array}$ & $\begin{array}{l}0.2359 \\
(0.600)\end{array}$ & $\begin{array}{c}0.3855^{n s} \\
(0.247)\end{array}$ & $\begin{array}{l}0.3332 \\
(1.16)\end{array}$ \\
\hline Dummy: Urban & $\begin{array}{c}-0.1148^{n s} \\
(0.697)\end{array}$ & $\begin{array}{l}0.2948 \\
(-0.390)\end{array}$ & $\begin{array}{c}-0.0998^{n s} \\
(0.773)\end{array}$ & $\begin{array}{l}0.3466 \\
(-0.29)\end{array}$ \\
\hline $\begin{array}{l}\text { Educational } \\
\text { Attainment }^{\mathrm{d}}\end{array}$ & $\begin{array}{c}-0.1097^{n s} \\
(0.319) \\
\end{array}$ & $\begin{array}{c}0.1098 \\
(-1.000)\end{array}$ & $\begin{array}{c}-0.2402^{n s} \\
(0.129) \\
\end{array}$ & $\begin{array}{c}0.1580 \\
(-1.52)\end{array}$ \\
\hline Years in Service & $\begin{array}{c}-0.0209^{n s} \\
(0.179)\end{array}$ & $\begin{array}{l}0.0155 \\
(-1.350)\end{array}$ & $\begin{array}{c}-0.3335^{*} \\
(0.086)\end{array}$ & $\begin{array}{l}0.0194 \\
(-1.71)\end{array}$ \\
\hline $\begin{array}{l}\text { Dummy: Regular } \\
\text { Permanent }\end{array}$ & $\begin{array}{l}0.5586^{*} \\
(0.100) \\
\end{array}$ & $\begin{array}{l}0.3372 \\
(1.660)\end{array}$ & $\begin{array}{l}0.7245^{*} \\
(0.068) \\
\end{array}$ & $\begin{array}{l}0.3970 \\
(1.83) \\
\end{array}$ \\
\hline Net Income in VSU & $\begin{array}{c}1.23 e-06^{n s} \\
(0.704)\end{array}$ & $\begin{array}{c}3.22 \mathrm{e}-06 \\
(0.380)\end{array}$ & $\begin{array}{c}4.16 e-06^{n s} \\
(0.527)\end{array}$ & $\begin{array}{c}6.56 e-06 \\
(0.63)\end{array}$ \\
\hline $\begin{array}{l}\text { Dummy: Other } \\
\text { Income }\end{array}$ & $\begin{array}{l}-0.1546^{n s} \\
(0.588)\end{array}$ & $\begin{array}{c}0.2847 \\
(-0.540)\end{array}$ & $\begin{array}{c}-0.2849^{n s} \\
(0.426)\end{array}$ & $\begin{array}{l}0.3579 \\
(-0.80)\end{array}$ \\
\hline Fair Administration $^{a}$ & $\begin{array}{l}0.3879^{* * *} \\
(<0.001)\end{array}$ & $\begin{array}{l}0.0803 \\
(4.830)\end{array}$ & $\begin{array}{l}0.5281^{* * *} \\
(<0.001)\end{array}$ & $\begin{array}{l}0.0817 \\
(6.46)\end{array}$ \\
\hline $\begin{array}{l}\text { Number of } \\
\text { Observation }\end{array}$ & \multicolumn{2}{|c|}{162} & \multicolumn{2}{|c|}{162} \\
\hline & \multicolumn{2}{|c|}{$F_{c}=5.350$} & \multicolumn{2}{|c|}{$\chi_{c}^{2}=73.75$} \\
\hline $\begin{array}{l}p \text {-value } \\
\text { (Two-tailed test) }\end{array}$ & \multicolumn{2}{|c|}{$<0.001$} & \multicolumn{2}{|c|}{$<0.001$} \\
\hline & \multicolumn{2}{|c|}{$R^{2}=0.3264$} & \multicolumn{2}{|c|}{ Pseudo $R^{2}=0.1268$} \\
\hline
\end{tabular}

Note: $\mathrm{a}$-scale of 1 to $10 ; \mathrm{b}-p$-value are enclosed by parentheses (Two-tailed test); $\mathrm{c}-\mathrm{z}$-value are enclosed by parentheses; d - 1-Elementary, 2-High school, 3-Bachelors level, 4-Bachelor's degree, 5-Master's degree, 6Doctoral degree; ns- not significant; ${ }^{*}$ - significant at $10 \%$ level; ${ }^{* *}$ - significant at $5 \%$ level; ${ }^{* \star *}$ - significant at $1 \%$ level 
By Breusch-Pagan test, it was found out that the variances of Model 2 are heteroscedastic $\left(\chi^{2}=10.62, p\right.$-value $\left.=0.0011\right)$, and by Ramsey RESET test $(F=0.74, p$-value $=0.53)$, the model has no omitted variables bias (Table 4). Hence, model 2 was corrected and adjusted to account for the heteroscedasticity problem to ensure a valid interpretation of the results. It was found out that the models had no problem of multicollinearity between pair of predictors (mean VIF $=1.18<10$ and it is revealed that the residuals are normal $(Z=3.91, p$-value $<0.001)$ by the Shapiro-Wilk test. However, by Kernel density, it shows that the graph of residuals is close to normality. For Model 2 (Table 4), both OLS and ordered logit are also significant at $1 \%$, which implies that there are econometric determinants that explain the variation of the actual happiness among VSU employees. Table 4 reveals that VSU employees are more likely not happy doing their job because it is challenging. Due to the heavy duties and responsibilities in their respective assignment, employees do not have much time for leisure activities which negatively affects their well-being (De Pater et al., 2009). However, they find their job enjoyable for both OLS and ordered logit models (Table 4). This implies that being an employee in VSU, they enjoy serving their clients and the government. This is inconsonant with the studies of Brockner et al. (1993) and Ketterman et al. (2016).

Table 4. Econometric models for the degree of happiness in working VSU and its influencing determinants (Model 2)

\begin{tabular}{|c|c|c|c|c|}
\hline \multirow{2}{*}{$\begin{array}{c}\text { Determinants of } \\
\text { Happiness }\end{array}$} & \multicolumn{2}{|c|}{ OLS Model 2} & \multicolumn{2}{|c|}{ Ordered Logit Model 2} \\
\hline & Coefficient (b) & Std. Error (c) & Coefficient (b) & Std. Error (c) \\
\hline Constant & $\begin{array}{c}1.4717^{* *} \\
(0.045)\end{array}$ & $\begin{array}{l}0.7293 \\
(2.02) \\
\end{array}$ & & \\
\hline $\begin{array}{l}\text { Dummy: Teaching } \\
\text { Faculty }\end{array}$ & $\begin{array}{c}0.0537^{n s} \\
(0.815)\end{array}$ & $\begin{array}{l}0.2296 \\
(0.23) \\
\end{array}$ & $\begin{array}{l}-0.2881^{n s} \\
(0.398)\end{array}$ & $\begin{array}{c}0.3410 \\
(-0.84) \\
\end{array}$ \\
\hline $\begin{array}{l}\text { Experience: } \\
\text { Routinary }\end{array}$ & $\begin{array}{c}0.0249^{n s} \\
(0.584)\end{array}$ & $\begin{array}{l}0.4534 \\
(0.55)\end{array}$ & $\begin{array}{l}0.0341^{n s} \\
(0.574)\end{array}$ & $\begin{array}{l}0.0607 \\
(0.56)\end{array}$ \\
\hline $\begin{array}{l}\text { Experience: } \\
\text { Creative }^{\mathrm{a}}\end{array}$ & $\begin{array}{l}0.0494^{n s} \\
(0.639)\end{array}$ & $\begin{array}{l}0.1050 \\
(0.47)\end{array}$ & $\begin{array}{c}0.1524^{n s} \\
(0.315)\end{array}$ & $\begin{array}{l}0.1515 \\
(1.01)\end{array}$ \\
\hline $\begin{array}{l}\text { Experience: } \\
\text { Challenging }^{a}\end{array}$ & $\begin{array}{c}-0.1378^{n s} \\
(0.185)\end{array}$ & $\begin{array}{l}0.1035 \\
(-1.33)\end{array}$ & $\begin{array}{c}-0.2213^{*} \\
(0.100)\end{array}$ & $\begin{array}{c}0.1355 \\
(-1.63)\end{array}$ \\
\hline $\begin{array}{l}\text { Experience: } \\
\text { Enjoyable }^{a}\end{array}$ & $\begin{array}{c}0.2976^{* * *} \\
(0.000)\end{array}$ & $\begin{array}{l}0.0834 \\
(3.57)\end{array}$ & $\begin{array}{c}0.4239^{* * *} \\
(0.001) \\
\end{array}$ & $\begin{array}{l}0.1288 \\
(3.39) \\
\end{array}$ \\
\hline Experience: Logical $^{a}$ & $\begin{array}{c}-0.0944^{n s} \\
(0.346)\end{array}$ & $\begin{array}{l}0.0999 \\
(-0.94)\end{array}$ & $\begin{array}{l}-0.1402^{\text {ns }} \\
(0.306)\end{array}$ & $\begin{array}{l}0.1369 \\
(-1.02)\end{array}$ \\
\hline $\begin{array}{l}\text { Experience: } \\
\text { Rewarding }^{\text {a }}\end{array}$ & $\begin{array}{c}0.2041^{* *} \\
(0.024)\end{array}$ & $\begin{array}{l}0.0892 \\
(2.29)\end{array}$ & $\begin{array}{l}0.2714^{* *} \\
(0.018)\end{array}$ & $\begin{array}{l}0.1152 \\
(2.36)\end{array}$ \\
\hline Matches one's Skill ${ }^{a}$ & $\begin{array}{c}-0.0623^{n s} \\
(0.510)\end{array}$ & $\begin{array}{l}0.0944 \\
(-0.66)\end{array}$ & $\begin{array}{c}-0.1339^{n s} \\
(0.315)\end{array}$ & $\begin{array}{c}0.1333 \\
(-1.00)\end{array}$ \\
\hline Social Relationship ${ }^{a}$ & $\begin{array}{l}0.3074^{* * *} \\
(<0.001)\end{array}$ & $\begin{array}{l}0.0842 \\
(3.65)\end{array}$ & $\begin{array}{l}0.4799^{* * *} \\
(<0.001)\end{array}$ & $\begin{array}{l}0.1198 \\
(4.01)\end{array}$ \\
\hline Fair Administration $^{a}$ & $\begin{array}{c}0.2090^{* * *} \\
(0.003)\end{array}$ & $\begin{array}{l}0.0689 \\
(3.03)\end{array}$ & $\begin{array}{l}0.3455^{* * *} \\
(<0.001)\end{array}$ & $\begin{array}{l}0.0929 \\
(3.72)\end{array}$ \\
\hline $\begin{array}{l}\text { Number of } \\
\text { Observation }\end{array}$ & \multicolumn{2}{|c|}{162} & \multicolumn{2}{|c|}{162} \\
\hline & \multicolumn{2}{|c|}{$F_{c}=14.10$} & \multicolumn{2}{|c|}{$\chi_{c}^{2}=104.17$} \\
\hline $\begin{array}{l}p \text {-value } \\
\text { (Two-tailed test) }\end{array}$ & \multicolumn{2}{|c|}{$<0.001$} & \multicolumn{2}{|c|}{$<0.001$} \\
\hline & \multicolumn{2}{|c|}{$R^{2}=0.4932$} & \multicolumn{2}{|c|}{ Pseudo $R^{2}=0.1791$} \\
\hline
\end{tabular}

Note: $a$ - scale of 1 to $10 ; b-p$-value are enclosed by parentheses (Two-tailed test); $c-z$-value are enclosed by parentheses; ns- not significant; * - significant at $10 \%$ level; ** - significant at $5 \%$ level; ${ }^{* * *}$ - significant at $1 \%$ level. 
The two models in Table 4 reveals that employees are happy when their job is rewarding. Concerning this, employees are willing to do their job and will be satisfied with whatever accomplishment they have done at the end of the day (Ketterman et al., 2016). According to the OLS and ordered logit model (Table 4), employees are socially interactive with the other employees, which positively increases their happiness. This implies that employees embrace their relationships, giving them support to work and encouragement to the challenges they have encountered. Additionally, employees closely related to other work members in the University feel comfortable and confident to do their job (Pooja et al., 2016). Table 4 also reveals that a fair administration positively affects the well-being of the employees. This further implies that no partial treatment of every employee in the University positively impacts their happiness.

Table 5 reveals that the variances of Model 3 are also heteroscedastic $\left(\chi^{2}=44.08, p\right.$-value $\left.<0.001\right)$ by Breusch-Pagan test and by Ramsey RESET test $(F=1.44, p$-value $=0.069)$ the model has omitted variables bias. So, it follows that the second model was corrected and adjusted to account for the heteroscedasticity problem and remove its variable bias. The model has no problem of multicollinearity between pair of predictors (mean VIF $=2.33<10$ ).

Table 5.Econometric models for the degree of happiness in working VSU and its influencing determinants (Model 3)

\begin{tabular}{|c|c|c|c|c|}
\hline \multirow{2}{*}{$\begin{array}{l}\text { Determinants of } \\
\text { Happiness }\end{array}$} & \multicolumn{2}{|c|}{ OLS Model 3} & \multicolumn{2}{|c|}{ Ordered Logit Model 3} \\
\hline & Coefficient (b) & Std. Error (c) & Coefficient (b) & Std. Error (c) \\
\hline Constant & $\begin{array}{l}1.8824^{n s} \\
(0.110)\end{array}$ & $\begin{array}{l}1.1718 \\
(1.61) \\
\end{array}$ & & \\
\hline $\begin{array}{l}\text { Dummy: Teaching } \\
\text { Faculty }\end{array}$ & $\begin{array}{c}-0.4864^{n s} \\
(0.192) \\
\end{array}$ & $\begin{array}{l}0.3711 \\
(-1.31) \\
\end{array}$ & $\begin{array}{l}-1.2150^{* * *} \\
(0.008)\end{array}$ & $\begin{array}{l}0.5488 \\
(-2.65) \\
\end{array}$ \\
\hline Social Security ${ }^{a}$ & $\begin{array}{l}-0.0278^{n s} \\
(0.641) \\
\end{array}$ & $\begin{array}{l}0.0595 \\
(-0.47) \\
\end{array}$ & $\begin{array}{c}0.0194^{n s} \\
(0.793) \\
\end{array}$ & $\begin{array}{l}0.0742 \\
(0.26) \\
\end{array}$ \\
\hline $\begin{array}{l}\text { Educational } \\
\text { Attainment }^{d}\end{array}$ & $\begin{array}{c}0.0184^{n s} \\
(0.849)\end{array}$ & $\begin{array}{l}0.0962 \\
(0.19)\end{array}$ & $\begin{array}{c}0.0123^{\text {ns }} \\
(0.923)\end{array}$ & $\begin{array}{l}0.1272 \\
(0.10) \\
\end{array}$ \\
\hline $\begin{array}{l}\text { Opportunities for } \\
\text { Promotion }^{\text {a }}\end{array}$ & $\begin{array}{c}0.2282^{* * *} \\
(0.001) \\
\end{array}$ & $\begin{array}{l}0.0690 \\
(3.30) \\
\end{array}$ & $\begin{array}{c}0.3136^{* * *} \\
(0.000) \\
\end{array}$ & $\begin{array}{l}0.0813 \\
(3.86) \\
\end{array}$ \\
\hline Bonus $^{a}$ & $\begin{array}{c}-0.0521^{n s} \\
(0.571) \\
\end{array}$ & $\begin{array}{l}0.0918 \\
(-0.57) \\
\end{array}$ & $\begin{array}{c}0.0035^{n s} \\
(0.973) \\
\end{array}$ & $\begin{array}{l}0.1032 \\
(0.03) \\
\end{array}$ \\
\hline Incentives $^{a}$ & $\begin{array}{c}0.0283^{n s} \\
(0.736)\end{array}$ & $\begin{array}{l}0.0836 \\
(0.34)\end{array}$ & $\begin{array}{l}-0.0181^{n s} \\
(0.847)\end{array}$ & $\begin{array}{l}0.0937 \\
(-0.19)\end{array}$ \\
\hline Awards ${ }^{a}$ & $\begin{array}{c}0.0685^{n s} \\
(0.306)\end{array}$ & $\begin{array}{l}0.0667 \\
(1.03)\end{array}$ & $\begin{array}{l}0.1090^{n s} \\
(0.156)\end{array}$ & $\begin{array}{l}0.0768 \\
(1.42)\end{array}$ \\
\hline Overtime Pay $^{\mathrm{a}}$ & $\begin{array}{c}0.0322^{n s} \\
(0.396) \\
\end{array}$ & $\begin{array}{l}0.0378 \\
(0.85) \\
\end{array}$ & $\begin{array}{l}0.0821^{*} \\
(0.100)\end{array}$ & $\begin{array}{l}0.0501 \\
(1.64) \\
\end{array}$ \\
\hline Social Relationship ${ }^{a}$ & $\begin{array}{l}0.2851^{* *} \\
(0.016)\end{array}$ & $\begin{array}{l}0.1172 \\
(2.43) \\
\end{array}$ & $\begin{array}{l}0.3138^{* *} \\
(0.018) \\
\end{array}$ & $\begin{array}{l}0.1323 \\
(2.37) \\
\end{array}$ \\
\hline Health $^{a}$ & $\begin{array}{l}0.2163^{*} \\
(0.109) \\
\end{array}$ & $\begin{array}{l}0.1343 \\
(1.61) \\
\end{array}$ & $\begin{array}{c}0.4177^{* * *} \\
(0.002) \\
\end{array}$ & $\begin{array}{l}0.1318 \\
(3.17) \\
\end{array}$ \\
\hline $\begin{array}{l}\text { Number of } \\
\text { Observation }\end{array}$ & \multicolumn{2}{|c|}{162} & \multicolumn{2}{|c|}{162} \\
\hline & \multicolumn{2}{|c|}{$F_{c}=5.49$} & \multicolumn{2}{|c|}{$\chi_{c}^{2}=91.88$} \\
\hline $\begin{array}{l}p \text {-value (Two-tailed } \\
\text { test) }\end{array}$ & \multicolumn{2}{|c|}{$<0.001$} & \multicolumn{2}{|c|}{$<0.001$} \\
\hline & \multicolumn{2}{|c|}{$R^{2}=0.4059$} & \multicolumn{2}{|c|}{ Pseudo $R^{2}=0.1590$} \\
\hline
\end{tabular}

Note: $\mathrm{a}$ - scale of 1 to $10 ; \mathrm{b}-p$-value are enclosed by parentheses (Two-tailed test); $\mathrm{c}-\mathrm{z}$-value are enclosed by parentheses; d - 1-Elementary, 2-High school, 3-Bachelors level, 4-Bachelor's degree, 5-Master's degree, 6-

Doctoral degree; ns- not significant; * - significant at $10 \%$ level; ** - significant at $5 \%$ level; ${ }^{* * *}$ - significant at $1 \%$ level. 
Moreover, by the Shapiro-Wilk test, it is revealed that the residuals are not normal $(Z=3.92$, $p$-value $<0.001)$, however, the Kernel density graph shows that the residuals are close to normality. Model 3 is also significant for both OLS and ordered logit models at a $1 \%$ level. This implies that some determinants in the model can explain the variation of the actual happiness among employees. Table 5 reveals that being a non-teaching employee is more like being happy, as shown in the ordered logit model.

A non-teaching or administrative employee has fixed work time, and their work cannot be brought at home. Moreover, their job is routinely in which it can be mastered. However, as for the teachers, their job can be done at home, and it is challenging since there are diverse subjects to be taught. The result is not consistent with Casinillo et al. (2020) since college teachers' workload is more demanding nowadays. Both OLS and the ordered logit model at a $1 \%$ level show that having an opportunity for promotion increases happiness. It is worth noting that being promoted will have additional income and benefits, providing more comfort (Kosteas, 2011; Folke \& Rickne, 2020).

Additionally, Table 5 reveals that the ordered logit model has shown that overtime pay will give employees more happiness. This result is consistent with the findings of Green and Heywood (2008) and Trejo (1991). At a 5\% level, both OLS and ordered logit model reveals that social relationship is a significant factor in happiness for the employees. This implies that employees are closely related to co-workers and other members in which they feel comfortable and confident doing their respective jobs (Dean Jr. \& Brass, 1985; Guazzelli \& Zilli, 2016). Lastly, the health of employees in the two models (Table 5) shows that if employees are healthy, then there is a higher likelihood of being happy and efficient in work. The result is parallel to Helliwell et al.'s (2012) study that deals with health and happiness. Furthermore, in Kozma and Stones' (1983) findings, health is a strong predictor of happiness.

\subsection{Conclusion}

The study focused on examining the socio-economic determinants of subjective happiness among employees of VSU. The results revealed that a non-teaching staff was satisfied, contented, and happy with their job compared to teaching faculty. This is due to the increasing demand for paper works in the academe nowadays. Hence, the University may implement a stress management program and lessen the work assignment for teaching staff. The University's administration must be fair and treat every employee without partiality and with respect and courtesy. Policymakers may also consider the employees' remuneration for the extra service rendered, like overtime pay and incentives for meritorious performance. Employees' well-being and work concerns must be heard and dealt with by the school administration objectively and consistently by fairness and ensuring no conflict of interest. Furthermore, to increase employees' level of happiness, the University may provide medical incentives and the right to have vacations to relieve stress.

\subsection{Recommendations}

For future research, it is recommended that a similar study should be conducted in any University with a larger sample size of employees to gather richer information on the determinants of subjective happiness. Variables related to employees' access to credit or loans must be included for further analysis on the economics of happiness which is a potential limitation of the current study.

\section{REFERENCES}

Agwu, M. O. (2013). Impact of Fair Reward System on Employees Job Performance in Nigerian Agip Oil Company Limited Port-Harcourt. Journal of Education, Society and Behavioural Science, 3(1), 47-64.

Brockner, J., Wiesenfeld, B. M., Reed, T., Grover, S., \& Martin, C. (1993). Interactive effect of job content and context on the reactions of layoff survivors. Journal of personality and social psychology, 64(2), 187.

Casinillo, L. F. (2020). Econometric Modelling On Satisfaction In Rice Farming Under Philippine Rice Tariffication Law. Journal of Research and Multidisciplinary, 3(2), 326-336.

Casinillo, L. F., Casinillo, E. L., \& Casinillo, M. F. (2020). On happiness in teaching: an ordered logit modeling approach. JPI (Jurnal Pendidikan Indonesia), 9(2), 290-300.

Chaiprasit, K. \& Santidhirakul, O. (2011). Happiness at Work of Employees in Small and Mediumsized Enterprises, Thailand. Procedia-Social and Behavioral Sciences, 25, 189- 200. 
De Pater, I. E., Van Vianen, A. E., Bechtoldt, M. N., \& Klehe, U. C. (2009). Employees 'challenging Job experiences and supervisors' evaluations of promotability. Personnel Psychology, 62(2), 297325.

De Stasio, S., Fiorilli, C., Benevene, P., Boldrini, F., Ragni, B., Pepe, A., \& Maldonado Briegas, . J. (2019). Subjective happiness and compassion are enough to increase teachers' work engagement? Frontiers in psychology, 10, 2268.

Dean Jr, J. W., \& Brass, D. J. (1985). Social interaction and the perception of job characteristics in an organization. Human Relations, 38(6), 571-582.

Delfino, A. P. (2019). Spiritual leadership and job satisfaction of teaching and non-teaching personnel of Partido state university. People: International Journal of Social Sciences, 5(2). 123 140.

Folke, O., \& Rickne, J. (2020). All the single ladies: Job promotions and the durability of marriage. American Economic Journal: Applied Economics, 12(1), 260-87.

Frey, B. S., \& Stutzer, A. (2012). The use of happiness research for public policy. Social choice and welfare, 38(4), 659-674.

Fryxell, G. E., \& Gordon, M. E. (1989). Workplace justice and job satisfaction as predictors of satisfaction with union and management. Academy of Management Journal, 32(4), 851-866.

Galup, S. D., Klein, G., \& Jiang, J. J. (2008). The impacts of job characteristics on IS employee satisfaction: A comparison between permanent and temporary employees. Journal of Computer Information Systems, 48(4), 58-68.

Guazzelli, G. P. and Zilli, J. B. (2016). Economics of happiness: A study on happiness indicators in university professors. Ecoforum, 5(1), 171-181.

Graham, C. (2004). The Economics of Happiness: Insights on Globalization from a novel approach, World Economics, 6(3), 41-55.

Graham, C. (2005). Insights on development from the economics of happiness. The World Bank Research Observer, 20(2), 201-231.

Green, C., \& Heywood, J. S. (2008). Does performance pay increase job satisfaction? Economica, 75(300), 710-728.

Helliwell, J., Layard, R. \& Sachs, J. (2012). World Happiness Report. New York. Earth Institute.

Kahneman, D and Krueger, A. B. (2006). Developments in the Measurement of Subjective WellBeing. Journal of Economic Perspectives, 20(1), 3-24.

Ketterman, D. B., Fu, C. Y., \& Jones-Holguin, T. C. (2016). Thank God it's Monday [TGIM]: Helping Career Practitioners Create A More Stable, Enjoyable Work Environment For Greater Job Satisfaction Using The Character Champions Framework. Career Planning and Adult Development Journal, 32(4), 81.

Kooij, D. T., De Lange, A. H., Jansen, P. G., Kanfer, R., \& Dikkers, J. S. (2011). Age and work-related motives: Results of a meta-analysis. Journal of Organizational Behavior, 32(2), 197-225.

Kosteas, V. D. (2011). Job satisfaction and promotions. Industrial Relations: A Journal of Economy and Society, 50(1), 174-194.

Kozma, A. \& Stones, M. J. (1983). Predictors of happiness. Journal of Gerontology, 38(5), 626- 628. Retrieved from https://doi.ord/10.1093/geronj/38.5.626

Lyubomirsky, S. \& Lepper, H. S. (1999). A measure of subjective happiness: Preliminary reliability and construct validation. Social Indicators Research, 46, 137-155.

Maenapothi, R. (2007). Happiness in the workplace indicator. Human resource development, National institute of development administration.

Mertoğlu, M. (2018). Happiness level of teachers and analyzing its relation with some variables. Asian Journal of Education and Training, 4(4), 396-402.

Ng, Y. K. (2002). The East-Asian Happiness Gap: Speculating on Causes and Implications. Pacific Economic Review, 7(1), 51-63.

Park, J. A., Han, J. R., \& Shin, D. Y. (2016). A Study on the Determinants of Years in Service of Youth Employee. Industry Promotion Research, 1(1), 27-33.

Perry, H. (2018). An investigation into the effects of permanent and non-permanent contracts on employee well-being and employment insecurity (Doctoral dissertation, Dublin, National College of Ireland). 
Pooja, A. A., De Clercq, D., \& Belausteguigoitia, I. (2016). Job stressors and organizational citizenship behavior: The roles of organizational commitment and social interaction. Human Resource Development Quarterly, 27(3), 373-405.

Proto, E. (2016). Are happy workers more productive? IZA World of Labor, 315, 1-8.

Trejo, S. J. (1991). The effects of overtime pay regulation on worker compensation. The American Economic Review, 81(4), 719-740.

Truxillo, D. M., \& Fraccaroli, F. (2013). Research themes on age and work: Introduction to the Special Issue. European Journal of Work and Organizational Psychology, 22(3), 249-252.

Štreimikienè and Grundey. (2009). Life Satisfaction and Happiness - The Factors in Work Performance. Guest Editorial, Economic \& Sociology, 2(1), 9-26.

Stutzer, A., \& Frey, B. S. (2012). Recent developments in the economics of happiness: A selective overview. Recent Developments in the Economics of Happiness: A Selective Overview. IZA Discussion Paper, (7078).

Stutzer, A., \& Frey, B. S. (2010). Recent advances in the economics of individual subjective wellbeing. Social Research: An International Quarterly, 77(2), 679-714.

\section{Correspondence:}

LEOMARICH F. CASINILLO

leomarichcasinillo02011990@gmail.com

https://orcid.org/0000-0003-3966-8836

EMILY L. CASINILLO

elagumbay12201990@gmail.com

https://orcid.org/0000-0001-7570-1790

MA. RACHEL KIM L. AURE

kim_aure@vsu.edu.ph

https://orcid.org/0000-0002-1477-2963 